\title{
Estimation of Energy Balance at the Individual and Herd Level Using Blood and Milk Traits in High-Yielding Dairy Cows ${ }^{1,2}$
}

\author{
M. Reist, ${ }^{\star} †$ D. Erdin, ${ }^{\star}$ D. von Euw, ${ }^{\star}$ K. Tschuemperlin, ${ }^{*}$ \\ H. Leuenberger,ł Y. Chilliard,§ H. M. Hammon, $\dagger$ C. Morel, $\dagger$ \\ C. Philipona, $\uparrow$ Y. Zbinden, $\uparrow$ N. Kuenzi,* and J. W. Blum† \\ *Institute of Animal Science, Group of Animal Breeding, Swiss Federal Institute of Technology, CH-8092 Zurich, Switzerland \\ †Division of Animal Nutrition and Physiology, Faculty of Veterinary Medicine, University of Berne, CH-3012 Berne, Switzerland \\ fInstitute of Animal Science, Research Station Chamau, Swiss Federal Institute of Technology, CH-6331 Huenenberg, Switzerland \\ $\S$ Herbivore Research Unit, National Institute for Agricultural Research (INRA), F-63122 St-Genès-Champanelle, France
}

\begin{abstract}
This study aimed to estimate individual and herdlevel energy balance (EB) using blood and milk traits in 90 multiparous high-yielding Holstein cows, held on a research farm, from wk 1 to 10 postpartum (p.p.) and to investigate the precision of prediction with successively decreased data sets simulating smaller herd sizes and with pooled samples. Dry matter intake, milk yield, and BW were measured daily from parturition through wk 10 p.p. Milk composition was determined 4 times per week, and milk acetone was measured weekly. Blood samples for the determination of metabolites, hormones, electrolytes, and enzyme activities were taken weekly from wk 1 to 10 p.p. between 0730 and 0900 . Body condition scores and ultrasonic measurements of backfat thickness and fat depth in the pelvic area were evaluated in wk 1, 4, and 8 p.p. Concentrations of glucose, cholesterol, urea, insulin, insulin-like growth factor- 1 , triiodothyronine, and thyroxine $\left(\mathrm{T}_{4}\right)$ in blood plasma and of lactose and urea in milk were positively correlated with EB, whereas concentrations of nonesterified fatty acids (NEFA), creatinine, albumin, $\beta$-hydroxybutyrate, and growth hormone and enzyme activities in blood, and concentrations of fat, protein, fat:lactose ratio, and acetone in milk were negatively correlated with EB. Leptin concentration was not corre-
\end{abstract}

\footnotetext{
Received November 27, 2001.

Accepted March 11, 2002.

Corresponding author: J. W. Blum; e-mail: juerg.blum@ itz.unibe.ch.

${ }^{1}$ Presented in part at the 11th International Conference on Production Diseases in Farm Animals, August 12-16, 2001, Department of Animal Science and Animal Health, The Royal Veterinary and Agricultural University, Fredriksberg, Copenhagen, Denmark [M. Reist, D. Erdin, D. von Euw, K. Tschümperlin, Y. Chilliard, H. M. Hammon, N. Künzi, and J. W. Blum (2001) Prediction of Energy Balance at the Individual and Herd Level by use of Blood and Milk Traits in High-Yielding Dairy Cows].

${ }^{2}$ Accepted as part of the Ph.D.-thesis of M. Reist by the Swiss Federal Institute of Technology, Zurich, Switzerland, September
} 2001. lated to EB over the first 10 wk p.p. To estimate EB linear mixed-effects, models were developed by backward selection procedures. The most informative traits for estimation of $\mathrm{EB}$ were the fat:lactose ratio in milk and NEFA and $\mathrm{T}_{4}$ concentrations in blood. The precision of estimation of EB in individual cows was low. Using blood in addition to milk traits did not result in higher precision of estimation of herd-level EB, and decreasing sample sizes considerably lowered the precision of EB prediction. Estimation of overall mean herd-level EB over the first 10 wk p.p. using pooled samples was precise even with small sample sizes, but does not consider the level of EB in particular weeks. In conclusion, estimation of herd-level EB at individual weeks using milk traits only has practical implication with herd sizes of $\geq 100$ cows if calving is highly seasonal and of $\geq 400$ cows if calving is uniformly distributed. Using blood in addition to milk traits does not improve precision of estimation of herd-level EB, regardless of sample size. (Key words: energy balance, dairy cow, estimation)

Abbreviation key: $\mathbf{A C}=$ acetone, $\mathbf{A P}=$ absorbable protein, $\mathbf{C 3 0}=$ cows fed $30 \%$ of total DMI as concentrate, C50 = cows fed 50\% of total DMI as concentrate, CF = crude fiber, CF-group = concentrate feeding group (C30 or C50), EB = energy balance, $\mathbf{E C M ~ = ~ e n e r g y ~}$ corrected milk, GH = growth hormone, $\mathbf{G L D H}=$ glutamate dehydrogenase, $\mathbf{L D H}=$ lactate dehydrogenase, p.p. $=$ postpartum, $\mathbf{T}_{\mathbf{3}}=3,5,3^{\prime}$-triiodthyronine, $\mathbf{T}_{\mathbf{4}}=$ thyroxine.

\section{INTRODUCTION}

High-yielding dairy cows are typically in a state of negative energy balance (EB) postpartum (p.p.) because the amount of energy required for maintenance of body tissue functions and milk production exceeds the amount of energy cows can consume. The degree of negative EB in the early p.p. period and the recovery rate from negative EB are critical for health status and productivity. Insufficient energy supply p.p. may result 
in a higher risk for metabolic disorders, e.g., ketosis (Andersson, 1988), in poor reproductive performance, e.g., a delay in onset of ovarian cycle (Butler and Smith, 1989; Staples et al., 1990; Butler, 2000; Reist et al., 2000), in low conception rates, and in elevated occurrence of inflammatory disease, e.g., endometritis (Dohoo and Martin, 1984; Markusfeld, 1984), and mastitis (Suriyasathaporn et al., 2000). However, estimation of energy status under field conditions is difficult, because energy content of the feed depends highly on environmental factors, such as climate, processing, and storage. Furthermore, estimates of DMI are inaccurate because there is variation with physiological state of the individual cow, ambient temperature, photoperiod, feeding strategy, and forage quality (Allen, 2000; Ingvartsen and Andersen, 2000). In addition, digestibility of feed and of energy-yielding substances and the efficiency of their further use depend on many factors. Therefore, assessments of energy ingested at the animal level might provide more reliable information.

Various metabolic and endocrine blood and milk traits, such as NEFA, ketone bodies, insulin, IGF-1, thyroid hormones (Blum et al., 1985; Kunz et al., 1985; Ronge et al., 1988; Lucy et al., 1992; Gustafsson and Emanuelson, 1996), milk fat, protein, lactose, fat:protein ratio, and fat:lactose ratio (Macleod et al., 1984; Grieve et al., 1986; Steen et al., 1996; Heuer et al., 2000), have been shown to be related to EB. Automated blood and milk analysis and estimation of energy status with multivariate models might therefore have potential use in promoting health and productivity of dairy herds.

Based on such observations, the study aimed to estimate individual and herd-level EB using blood and milk traits in high-yielding dairy cows from wk 1 to 10 p.p. Heuer et al. (2000) reported that herd-mean EB can be adequately estimated with milk test-day information in large dairy herds, but that herd size limits the precision of prediction. In Switzerland, herds are rather small. For this reason it was tested, whether in small herds EB can be better estimated when-in addition to milk test-day information-various metabolic, enzymatic, and endocrine blood traits are incorporated into the models for EB estimation. Furthermore, the precision of prediction at herd-level EB with pooled herd samples was investigated.

\section{MATERIALS AND METHODS}

\section{Animals, Husbandry, Feeding Plan, Ration Composition, and Calculation of Energy Balance}

The experimental procedures followed the Swiss Law on Animal Protection and were approved by the Com- mittee for the Permission of Animal Experiments of the Canton of Zug, Zug, Switzerland.

Multiparous dairy cows $(\mathrm{n}=90 ; 86$ Holstein-Friesian and 4 Red Holstein) of parities 2 to 7 were studied from wk 2 antepartum to wk 20 p.p. at the research farm Chamau of the Swiss Federal Institute of Technology, Huenenberg, Switzerland. The herd-mean 305-d milk production was $9434 \pm 1067$ (mean \pm SD) kg energycorrected milk (ECM). The animals were housed in a free-stall barn and were held in free-stall groups of 12 cows. Each free-stall group was equipped with 12 mangers for forage and one automatic feeder for concentrate. Calving seasons were spring (April and May) and fall (November and December). Cows calved in four groups of equal size from fall 1998 to spring 2000.

The feeding plan is summarized in Table 1. During the dry period, cows were fed a roughage mix containing $5 \mathrm{MJ} \mathrm{NE}_{\mathrm{L}} / \mathrm{kg}$ DM. From wk 4 a.p. until calving, cows received the same roughage mix as p.p. containing $6 \mathrm{MJ}$ $\mathrm{NE}_{\mathrm{L}} / \mathrm{kg} \mathrm{DM}$ and, additionally, concentrate in increasing quantities from 0 to $40 \%$ of the calculated amount p.p. After parturition, cows were fed a roughage mix ad libitum (6 $\mathrm{MJ} \mathrm{NE}_{\mathrm{L}} / \mathrm{kg} \mathrm{DM}$ ), which was freshly provided four times per day. Mangers for roughage were fixed on electronic balances. The concentrate was restricted provided by automatic feeders. Two groups (C30 and C50) were formed based on differences in the total amount of concentrate provided. From wk 1 to 10 p.p., C30 cows $(n=45)$ received concentrate in amounts corresponding to $30 \%$ of their individual DMI of the previous week and C50 cows $(n=45)$ in amounts corresponding to $50 \%$, respectively. The two groups were balanced for parity, BCS a.p., BW a.p., calving season, and potential for milk production. The cows had access to roughage and concentrate during $24 \mathrm{~h}$. Individual roughage and concentrate intake of each animal were continuously recorded over $24 \mathrm{~h}$ during the whole study period. Minerals and vitamins were fed according to calculated needs (Kessler, 1999), and sodium chloride was provided ad libitum.

The compositions of the rations consumed are shown in Table 2. The roughage mix was composed of grass silage, whole plant corn silage, and grass hay and was kept at approximately $6 \mathrm{MJ} \mathrm{NE}_{\mathrm{L}} / \mathrm{kg} \mathrm{DM}$. The concentrate contained $8 \mathrm{MJ} \mathrm{NE}_{\mathrm{L}} / \mathrm{kg} \mathrm{DM}$, and its components were individually mixed according to lactation week and concentrate feeding group (C30 or C50) in order to attain the desired ratio between potentially absorbable protein $(\mathbf{A P})$ and $\mathrm{NE}_{\mathrm{L}}$ in the total ration for each individual cow (Table 2). Feed was sampled on a weekly basis, and DM content was determined. Feed was analyzed for $\mathrm{CP}$, crude fiber $(\mathbf{C F}), \mathrm{AP}$, and $\mathrm{NE}_{\mathrm{L}}$ at the Swiss Federal Research Station for Animal Production, Posieux, Switzerland, on a monthly basis (RAP, 1999). 
Table 1. Feeding plan.

\begin{tabular}{|c|c|c|c|c|}
\hline \multirow[b]{2}{*}{ Stage of lactation } & \multirow[b]{2}{*}{ Roughage } & \multicolumn{2}{|c|}{ Concentrate } & \multirow[b]{2}{*}{$\mathrm{AP}^{3} / \mathrm{NE}_{\mathrm{L}}$ ratio } \\
\hline & & $\mathrm{C} 30^{1}$ & $\mathrm{C} 50^{2}$ & \\
\hline Drying off to wk 5 a.p. ${ }^{4}$ & $\begin{array}{l}5 \mathrm{MJ} \mathrm{NE}_{\mathrm{L}} \\
\text { ad libitum }\end{array}$ & - & - & - \\
\hline Wk 4 to 1 a.p. ${ }^{4}$ & 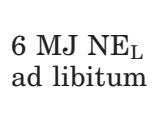 & $\begin{array}{l}\text { of quantity p.p. }{ }^{5} \\
\text { in increasing } \\
\text { amounts }\end{array}$ & $\begin{array}{l}\text { of quantity p.p. } \\
\text { in increasing } \\
\text { amounts }\end{array}$ & - gradually \\
\hline Wk 1 to 10 p.p. ${ }^{5}$ & 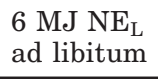 & $\begin{array}{l}30 \% \text { of total } \\
\text { DMI }\end{array}$ & $\begin{array}{l}50 \% \text { of total } \\
\text { DMI }\end{array}$ & $\begin{array}{l}\text { changed from } \\
17 \text { to } 15 \mathrm{~g} / \mathrm{MJ}\end{array}$ \\
\hline $\begin{array}{l}{ }^{1} \mathrm{C} 30=30 \% \text { of total DI } \\
{ }^{2} \mathrm{C} 50=50 \% \text { of total DI } \\
{ }^{3} \mathrm{AP}=\text { Potentially inte } \\
{ }^{4} \text { a.p. }=\text { Antepartum. } \\
{ }^{5} \text { p.p. = Postpartum. }\end{array}$ & $\begin{array}{l}\text { concentrat } \\
\text { concentrat } \\
\text { ly absorbal }\end{array}$ & $\begin{array}{l}\text { m wk } 1 \text { to } 10 \text { p.p. } \\
\text { m wk } 1 \text { to } 10 \text { p.p. } \\
\text { otein. }\end{array}$ & & \\
\hline
\end{tabular}

The BW was determined twice daily by weighing cows on an electronic balance after milking. The EB was calculated over the first 10 wk p.p. from energy-corrected milk yield (ECM), $\mathrm{NE}_{\mathrm{L}}$ intake, and $\mathrm{BW}$ using the following equation: $\mathrm{EB}=\left[\mathrm{NE}_{\mathrm{L}}\right.$-intake $-(\mathrm{kg} \mathrm{ECM}$ $\left.\times 3.14+0.293 \times \mathrm{kg} \mathrm{BW}{ }^{0.75}\right)$ ], according to Jans and Kessler (1999).

\section{Blood Traits}

Blood samples were taken from the jugular vein between 0730 and 0900 using evacuated tubes containing dipotassium-EDTA (1.8 g/L) or no anticoagulant, from wk 1 to 10 p.p. on a weekly basis. Blood samples with the anticoagulant were immediately put on ice, whereas tubes without anticoagulant (for recovery of serum) were left at room temperature until clotting was finished (within $30 \mathrm{~min}$ ). Tubes were then centrifuged for $20 \mathrm{~min}$ at $1500 \times \mathrm{g}$. BHBA, sodium, potassium, chlorine, calcium, phosphorus, magnesium, lactate dehydrogenase (LDH), glutamate dehydrogenase (GLDH), and aspartate aminotransferase (AST) were determined in serum. Glucose, NEFA, cholesterol, creatinine, albumin, urea, insulin, IGF-1, growth hormone (GH), 3,5,3'triiodothyronine $\left(\mathbf{T}_{3}\right)$, and thyroxine $\left(\mathbf{T}_{4}\right)$ were determined in plasma. The samples were stored at $-20^{\circ} \mathrm{C}$ until analyzed at the Division of Animal Nutrition and Physiology, University of Berne, Switzerland, as described by Aeberhard et al. (2001b) and Bruckmaier et al. (1998). For the determination of plasma leptin concentrations in duplicates, the specific double-antibody radioimmunoassay described by Delavaud et al. (2000) was followed, with slight modifications. Instead of anti-ovine $\mathrm{Ab} 7137$ leptin antiserum, $\mathrm{Ab} 8172$ was used in a final dilution of 1:15'000. After addition of ${ }^{125}$ I-ovine leptin, the incubation continued for an additional $44 \mathrm{~h}$ instead of $20 \mathrm{~h}$. As second antibody, goat anti-rabbit IgG was used instead of ram anti-rabbit IgG. It was diluted 1:50 in horse serum for standard curves, nonspecific binding tubes, and blanks and 1:50 in incubation buffer for the unknown plasma samples.

Table 2. Least squares means $\pm \mathrm{SD}$ of compositions of rations consumed from wk 1 to 10 p.p. ${ }^{1}$

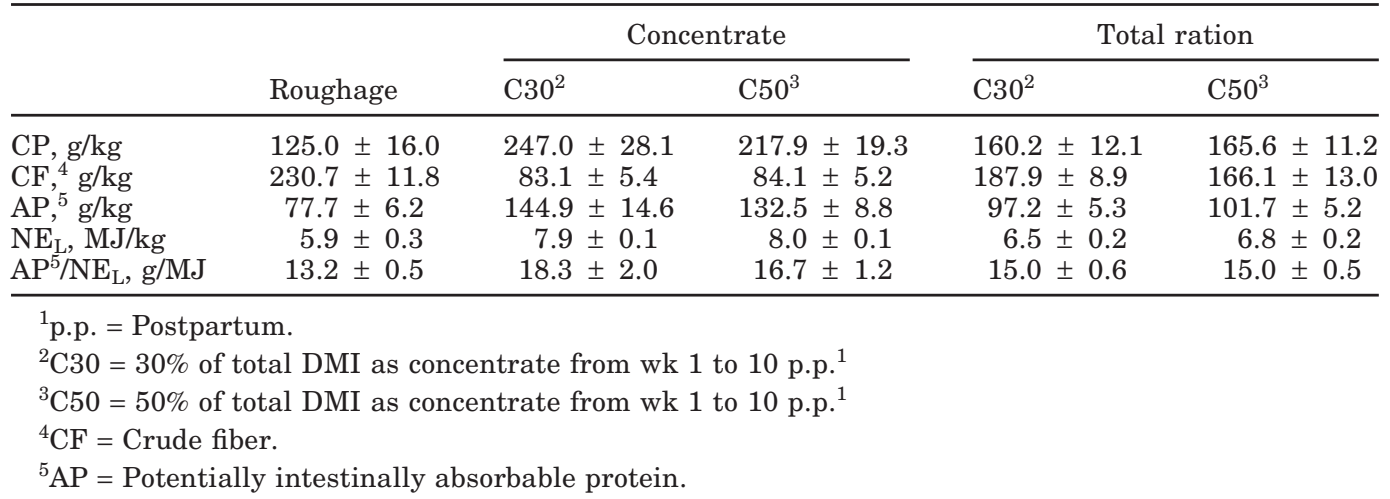




\section{Milk Traits}

Milk yield was measured twice daily. Time of milking was between 0430 and 0630 and between 1530 and 1730. Milk samples for determination of acetone (AC) were taken once per week (Tuesday morning) from wk 1 to 10 p.p., frozen immediately after milking and stored at $-20^{\circ} \mathrm{C}$ until analyzed. Concentrations of $\mathrm{AC}$ were determined by flow injection analysis (Marstorp et al., 1983; Reist et al., 2000) at the Division of Animal Nutrition and Physiology, University of Berne, Switzerland. Milk samples for the determination of milk fat, protein, lactose, and urea were taken four times per week (Monday and Wednesday evening, Tuesday and Thursday morning) and analyzed at the laboratory of the Swiss Brown Cattle Breeders' Federation, Zug, Switzerland. ECM was calculated as $[(0.038 \times g$ crude fat $+0.024 \times g$ crude protein $+0.017 \times g$ lactose $) \times \mathrm{kg}$ milk $\div 3.14$. The 305 -d standard lactation milk yields were calculated using the coefficients of the Holstein Association of Switzerland, Posieux, Switzerland.

\section{Statistical Analysis and Model Development}

Level of significance was set at $P<0.05$ throughout the paper. S-PLUS 2000 Professional Release (MathSoft, 1999) statistical software was used. Mixed-effects models were fitted using the NLME 3.4 library (Pinheiro and Bates, 2000) for S-PLUS.

Incomplete test-day records and test-day records of cows under a medical or preventive treatment, which might have influenced metabolic or endocrine status, were omitted. Thus, 859 test-day records of 90 cows from wk 1 to 10 p.p. were available for calculations.

Descriptive statistical analysis revealed that a considerable number of traits was not normally distributed. Therefore, NEFA, creatinine, BHBA, leptin, insulin, IGF-1, GH, $\mathrm{T}_{4}, \mathrm{LDH}, \mathrm{GLDH}, \mathrm{AST}$, milk AC, milk fat, milk protein, fat:protein ratio, and fat:lactose ratio were logarithmically transformed prior to analysis. Correlations between EB and the various blood and milk traits were calculated as Pearson's correlations.

Linear mixed-effects models of the form $\mathrm{y}_{\mathrm{i}}=\mathrm{X}_{\mathrm{i}} \beta+$ $\mathrm{Z}_{\mathrm{i}} \mathrm{b}_{\mathrm{i}}+\varepsilon_{\mathrm{i}}$, where $\mathrm{y}_{\mathrm{i}}$ is the response vector, $\beta$ is the vector of fixed effects, $b_{i}$ is the vector of random effects, $X_{i}$ and $\mathrm{Z}_{\mathrm{i}}$ are the fixed effects and random effects regressor matrices, and $\varepsilon_{\mathrm{i}}$ is the within-group error vector, were used to estimate EB considering blood and milk traits from wk 1 to 10 p.p. Models $(n=6)$ were fitted from varying basic models by backward elimination procedures, using a type I-error of $P<0.05$. In each of these basic models, EB was the response variable and the animal was the repeatedly studied random effect, while the composition of the fixed effects, which are the physically measurable and recordable data to estimate EB, varied (Table 3). The models were fitted as follows:

- Model 1 was fitted from a basic model containing the fixed effects concentrate feeding group (CFgroup), parity (dichotomized as 2 and $\geq 3$ ), and week of sampling at the categorical scale, and ECM and the different blood and milk traits at the continuous scale.

- Model 2 was derived from Model 1. Further blood and milk traits were eliminated stepwise from Model 1, regardless of the type I-error, apart from the three most informative ones. Elimination was based on the measure of determination $\left(\mathrm{R}^{2}\right)$ of the fixed effects. The rationale for this elimination of traits beyond a type I-error of $P<0.05$ was to reduce expenditures for laboratory analyses with respect to a potential practical application.

- Model 3 was fitted from a basic model containing the determined blood and milk traits only, i.e., information about CF group, parity, sampling week and ECM was omitted.

- Model 4 was derived from Model 3. Further blood and milk traits were eliminated stepwise from Model 3, apart from the three most informative ones, for the same reasons as in Model 2. Again, elimination was based on the $R^{2}$ of the fixed effects.

- Model 5 was fitted from a basic model containing the fixed effects CF group, parity (dichotomized as 2 and $\geq 3$ ) and week of sampling at the categorical scale, and ECM and milk traits at the continuous scale. Blood traits were not included in this model.

- Model 6 was fitted from a basic model containing as fixed effects milk traits only, i.e., information about blood traits, CF group, sampling week, parity, and ECM was omitted.

To avoid colinearity, correlation structures of the fixed effects were examined prior to calculation. If the absolute value of the coefficient of correlation between two variables exceeded $r=0.5$, the variable correlating stronger to EB was incorporated into the basic model and the other was omitted. The final models were crossvalidated and the residual plots of the final models were used as criterion for the model fit regarding homogenous variance assumption. To estimate precision of estimation of EB at the individual animal level, standard deviations (SD) of observed minus estimated EB (residuals) were calculated for the six final models.

\section{Estimation of Herd-Level Energy Balance}

Decreasing sample and herd size was simulated by random selection of cow test-days. In the first simulation, monthly test-days were randomly selected over 
Table 3. Composition of the fixed effects of the basic models.

\begin{tabular}{|c|c|c|c|c|c|c|}
\hline & Milk traits & Blood traits & CF-group ${ }^{1}$ & Week p.p. ${ }^{2}$ & Parity & $\mathrm{ECM}^{3}$ \\
\hline Model 1 & - & - & - & - & - & - \\
\hline Model 2 & - & - & - & - & - & - \\
\hline Model 3 & • & - & & & & \\
\hline Model 4 & - & - & & & & \\
\hline Model 5 & - & & - & - & - & - \\
\hline Model 6 & $\bullet$ & & & & & \\
\hline
\end{tabular}

the first 8 wk of lactation according to the current Swiss milk recording system in the field, resulting in data sets of 180 test-days. In the second simulation, one test-day per cow was randomly selected over the first $10 \mathrm{wk}$ of lactation, resulting in data sets of 90 test-days. In the third simulation, one test-day of 40 randomly identified cows was randomly selected over the first 10 wk p.p., resulting in data sets of 40 testdays. Finally, in the fourth simulation, one test-day of 20 randomly identified cows was randomly selected over the first 10 wk p.p., resulting in data sets of 20 test-days. Each simulation was repeated 200 times, which was considered sufficient for stable SD, of the resulting herd means, according to Heuer et al. (2000). The precision of estimation of weekly EB with reduced data sets was expressed in $1 \mathrm{SD}$. These weekly SD and the average number of cows in the sample based on the 200 runs were computed for each of the four simulations with each of the six final models.

Finally, precision of estimation of mean overall EB from wk 1 to 10 p.p. was computed as described in the precedent section. Pooling of the samples was simulated in order to minimize laboratory expenditures with respect to a possible practical application. By pooling the individual samples of a herd, cow-specific information, e.g., lactation week and CF-group, got lost. Thus, only models 3,4 , and 6 , which do not include the fixed-effects week of sampling, CF-group, and ECM, were considered for this part. Again, simulations were repeated 200 times. The precision of prediction of mean overall EB from wk 1 to 10 p.p. with reduced data sets was expressed in $1 \mathrm{SD}$ of the difference between mean EB estimated with all data sets and mean EB predicted with the reduced data sets.

\section{RESULTS}

\section{Correlation of Energy Balance with Blood and Milk Traits}

Pearson's correlations of blood and milk traits with EB from wk 1 to 10 p.p. are presented in Table 4 .
Apart from leptin, each of the determined metabolic, endocrine, and enzymatic blood traits correlated significantly with EB, as well as the determined milk components. Concentrations of NEFA correlated strongest $(r=-0.685)$ with $\mathrm{EB}$, followed by concentrations of glucose $(\mathrm{r}=0.457)$, BHBA $(\mathrm{r}=-0.451)$, and $\mathrm{T}_{4}(\mathrm{r}=0.418)$. In milk, the order of correlation was fat:lactose ratio $(\mathrm{r}=-0.589)$, followed by fat $(\mathrm{r}=$ $-0.565)$, fat:protein ratio $(\mathrm{r}=-0.496)$, and $\mathrm{AC}(\mathrm{r}=$ $-0.410)$.

\section{Model Development and Estimation of Individual and Herd-Level Energy Balance}

The six final mixed-effects models selected for estimation of EB are presented in Tables 5 to 10 (Models

Table 4. Pearson's correlations of blood and milk traits with energy balance wk 1 to 10 p.p. ${ }^{1}$

\begin{tabular}{lrl}
\hline Trait & $\mathrm{r}$ & $P$ \\
\hline Blood metabolites & & \\
NEFA & -0.685 & $<0.001$ \\
Glucose & 0.456 & $<0.001$ \\
$\beta$-hydroxybutyrate & -0.451 & $<0.001$ \\
Cholesterol & 0.406 & $<0.001$ \\
Creatinine & -0.415 & $<0.001$ \\
Urea & 0.259 & $<0.001$ \\
Albumin & -0.137 & $<0.001$ \\
Blood hormones & & \\
Thyroxine & 0.418 & $<0.001$ \\
Insulin-like growth factor-1 & 0.320 & $<0.001$ \\
3,5,3'-Triiodothyronine & 0.270 & $<0.001$ \\
Insulin & 0.230 & $<0.001$ \\
Growth hormone & -0.217 & $<0.001$ \\
Leptin & -0.027 & 0.437 \\
Blood enzymes & & \\
Lactate dehydrogenase & -0.199 & $<0.001$ \\
Aspartate amino transferase & -0.154 & $<0.001$ \\
Glutamate dehydrogenase & -0.114 & $<0.001$ \\
Milk traits & & \\
Fat:lactose ratio & -0.589 & $<0.001$ \\
Milk fat & -0.565 & $<0.001$ \\
Fat:protein ratio & -0.496 & $<0.001$ \\
Milk acetone & -0.410 & $<0.001$ \\
Lactose & 0.363 & $<0.001$ \\
Milk protein & -0.185 & $<0.001$ \\
Milk urea & 0.103 & 0.002 \\
\hline 1pp - Postpartwm & &
\end{tabular}

${ }^{1}$ p.p. = Postpartum. 
Table 5. Regression coefficients of Model $1 \dagger$ selected for estimation of energy balance [MJ $\left.\mathrm{NE}_{\mathrm{L}}\right]$.

\begin{tabular}{|c|c|c|c|c|}
\hline Parameter & \multirow{2}{*}{$\begin{array}{c}\text { Coefficient } \\
83.81\end{array}$} & \multicolumn{2}{|c|}{$95 \%$ Confidence interval } & \multirow{2}{*}{$\frac{P}{<0.001}$} \\
\hline & & 39.59 & 128.03 & \\
\hline \multirow{2}{*}{ CF-Group ${ }^{1}$} & 0 & & & \\
\hline & -14.84 & -19.29 & -10.38 & $<0.001$ \\
\hline Week 1 & 0 & & & \\
\hline Week 2 & 4.46 & 1.55 & 7.36 & 0.003 \\
\hline Week 3 & 15.40 & 12.03 & 18.77 & $<0.001$ \\
\hline Week 4 & 17.25 & 13.60 & 20.90 & $<0.001$ \\
\hline Week 5 & 20.23 & 16.48 & 23.99 & $<0.001$ \\
\hline Week 6 & 20.42 & 16.68 & 24.17 & $<0.001$ \\
\hline Week 7 & 21.71 & 17.94 & 25.48 & $<0.001$ \\
\hline Week 8 & 23.10 & 19.31 & 26.89 & $<0.001$ \\
\hline Week 9 & 24.22 & 20.48 & 27.95 & $<0.001$ \\
\hline Week 10 & 24.81 & 20.99 & 28.63 & $<0.001$ \\
\hline $\mathrm{ECM},{ }^{4} \mathrm{~kg}$ & -1.98 & -2.18 & -1.77 & $<0.001$ \\
\hline $\mathrm{NEFA}, \mu \mathrm{mol} / \mathrm{L}, \mathrm{ln}$ & -1.71 & -2.99 & -0.42 & 0.010 \\
\hline Creatinine, $\mu \mathrm{mol} / \mathrm{L}, \ln$ & -13.47 & -23.08 & -3.86 & 0.007 \\
\hline $\mathrm{T}_{4},{ }^{5} \mathrm{nmol} / \mathrm{L}, \mathrm{ln}$ & 7.36 & 4.27 & 10.44 & $<0.001$ \\
\hline Fat:lactose ratio milk, ln & -66.12 & -72.57 & -59.66 & $<0.001$ \\
\hline \multicolumn{5}{|c|}{$\begin{array}{l}\dagger \text { Cow is selected as random effect. Sample size }(n)=859 \text { test-day records. } R^{2} \text { of fixed effects }=0.711, R^{2} \\
\text { f complete model }=0.900 \text {. }\end{array}$} \\
\hline \multicolumn{5}{|c|}{${ }^{1} \mathrm{CF}$-Group = Concentrate-feeding group. } \\
\hline \multicolumn{5}{|c|}{${ }^{2} \mathrm{C} 30=30 \%$ of total DMI as concentrate from wk 1 to 10 p.p. ${ }^{6}$} \\
\hline \multicolumn{5}{|c|}{${ }^{3} \mathrm{C} 50=50 \%$ of total DMI as concentrate from wk 1 to 10 p.p. ${ }^{6}$} \\
\hline \multicolumn{5}{|c|}{${ }^{4} \mathrm{ECM}=$ Energy-corrected milk yield. } \\
\hline \multicolumn{5}{|l|}{${ }^{5} \mathrm{~T}_{4}=$ Thyroxine. } \\
\hline${ }^{6}$ p.p. = Postpartum. & & & & \\
\hline
\end{tabular}

1 to 6 , respectively). The regression coefficients, $95 \%$ confidence intervals, $P$ values, and $\mathrm{R}^{2}$ are shown. Residual plots of the six final models are presented in Figure 1, together with the appropriate SD.
Measure of determination of the fixed effects $\left(\mathrm{R}^{2}=\right.$ $0.711)$ and precision of estimation of individual EB (1 $\mathrm{SD}=12.99 \mathrm{MJ} \mathrm{NE}_{\mathrm{L}}$; Figure 1) were highest in the most complete model (Model 1; Table 5), which included the

Table 6. Regression coefficients of Model $2 \dagger$ selected for estimation of energy balance [MJ NE $\left.E_{L}\right]$.

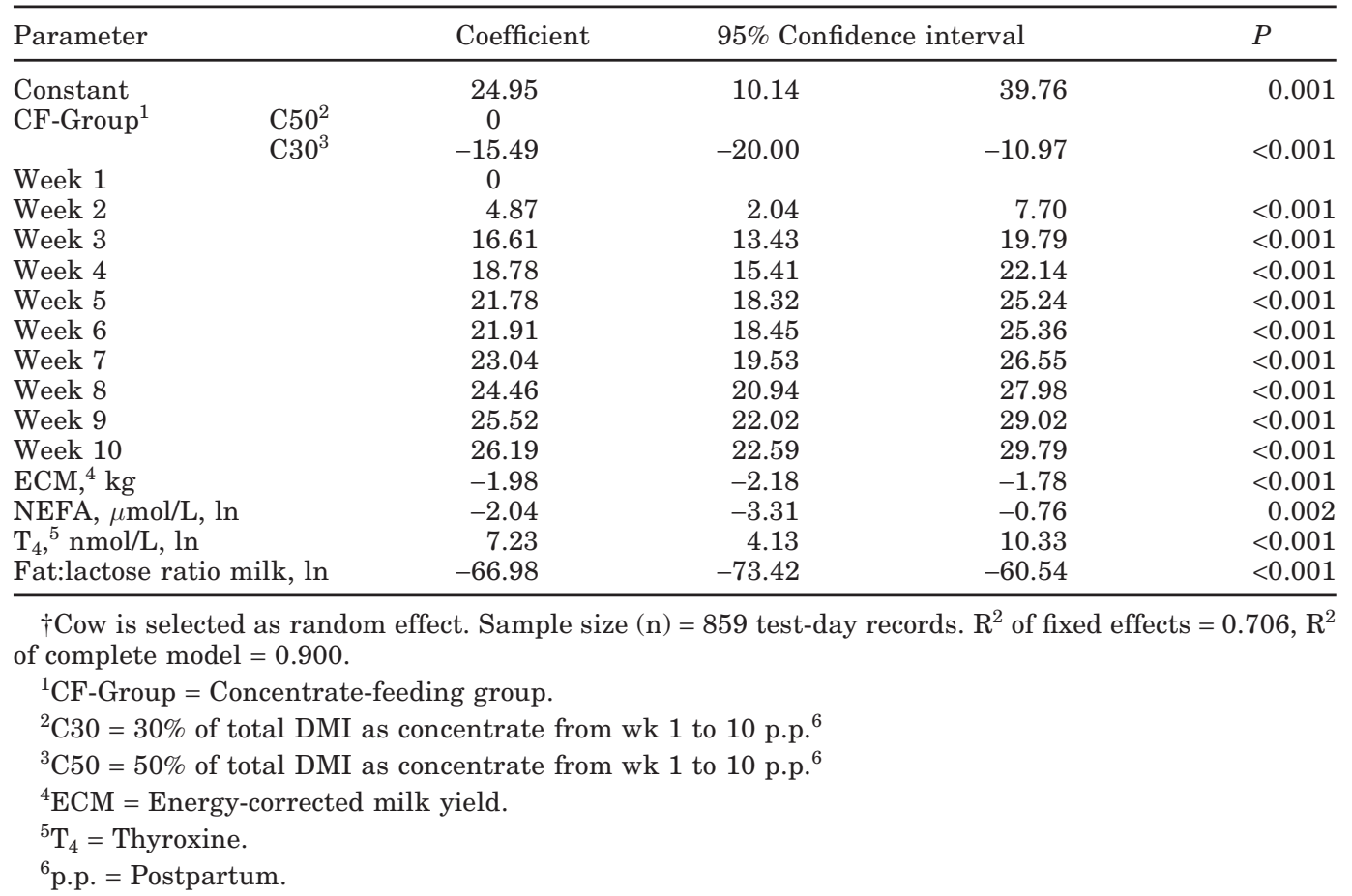


Table 7. Regression coefficients of Model $3 \dagger$ selected for estimation of energy balance [MJ $\left.\mathrm{NE}_{\mathrm{L}}\right]$.

\begin{tabular}{|c|c|c|c|c|}
\hline \multirow{2}{*}{$\frac{\text { Parameter }}{\text { Constant }}$} & \multirow{2}{*}{$\begin{array}{c}\text { Coefficient } \\
-2.19\end{array}$} & \multicolumn{2}{|c|}{ 95\% Confidence interval } & \multirow{2}{*}{$\begin{array}{l}P \\
0.835\end{array}$} \\
\hline & & -22.69 & 18.31 & \\
\hline NEFA, $\mu \mathrm{mol} / \mathrm{L}$, ln & -5.26 & -6.76 & -3.76 & $<0.001$ \\
\hline Cholesterol, $\mathrm{mmol} / \mathrm{L}$ & 3.29 & 2.44 & 4.14 & $<0.001$ \\
\hline Albumin, g/L & -0.71 & -1.16 & -0.26 & 0.002 \\
\hline $\mathrm{T}_{4},{ }^{1} \mathrm{nmol} / \mathrm{L}, \mathrm{ln}$ & 9.51 & 5.50 & 13.52 & $<0.001$ \\
\hline Fat:lactose ratio milk, ln & -53.11 & -60.58 & -45.63 & $<0.001$ \\
\hline Milk urea, $\mathrm{mmol} / \mathrm{L}$ & -4.07 & -5.53 & -2.60 & $<0.001$ \\
\hline
\end{tabular}

$\dagger$ Cow is selected as random effect. Sample size $(n)=859$ test-day records. $R^{2}$ of fixed effects $=0.536, R^{2}$ of complete model $=0.839$.

${ }^{1} \mathrm{~T}_{4}=$ Thyroxine.

fixed effects CF-group, sampling week, ECM, and all significant blood and milk traits, namely plasma NEFA, creatinine, $\mathrm{T}_{4}$, and the fat:lactose ratio in milk. Model 2 was derived from Model 1 by stepwise elimination of blood and milk traits, leaving only the three most informative ones: NEFA and $\mathrm{T}_{4}$ in plasma and the fat:lactose ratio in milk. In Model $2, \mathrm{R}^{2}$ of the fixed effects accounted for 0.706 (Table 6) and 1 SD of observed minus estimated $\mathrm{EB}$ for $13.09 \mathrm{MJ} \mathrm{NE}$ (Figure 1), respectively. Model 3 included as fixed effects blood and milk traits only, i.e., information about CFgroup, sampling week, and ECM was omitted. EB was estimated best by plasma NEFA, cholesterol, albumin, and $\mathrm{T}_{4}$, the fat:lactose ratio in milk, and milk urea. The $\mathrm{R}^{2}$ of the fixed effects was 0.536 (Table 7), and precision of estimation was 16.52 $\mathrm{MJ} \mathrm{NE}_{\mathrm{L}}$ (Figure 1). Model 4 was derived from Model 3 by stepwise elimination of blood and milk traits, leaving only the three most informative ones. These were the same as in Model 2, namely plasma NEFA and $\mathrm{T}_{4}$ and the fat:lactose ratio in milk. The $\mathrm{R}^{2}$ of the fixed effects accounted for 0.524 (Table 8) and $1 \mathrm{SD}$ of the residuals for 16.70 MJ NE $\mathrm{L}_{\mathrm{L}}$ (Figure 1), respectively. Model 5 included the fixed effects CF-group, sampling week, ECM, the fat:lactose ratio, and milk AC, but no blood traits. The $\mathrm{R}^{2}$ of the fixed effects was 0.695 (Table 9 ), and precision of estimation was 13.39 $\mathrm{MJ} \mathrm{NE}_{\mathrm{L}}$ (Figure 1). Model 6 included milk protein, urea, and $\mathrm{AC}$ and the fat:lactose ratio as fixed effects. The $R^{2}$ of the fixed effects accounted for 0.330 (Table 10) and $1 \mathrm{SD}$ of the residuals for $19.76 \mathrm{MJ} \mathrm{NE}$ (Figure 1).
Observed and estimated weekly EB with the six final Models and the complete test-days $(\mathrm{n}=859)$ from wk 1 to 10 are presented in Table 11 . For the reduced data sets simulating smaller herd sizes, average number of cows in the samples at the individual weeks are specified. Furthermore, precision of predicted herdmean EB at decreasing sample (n) and herd size is shown.

Differences between observed and estimated EB with the complete data set $(n=859)$ were small for Models 1, 2, and 5. For Models 3, 4, and 6 these differences were greater, especially in wk 2 p.p. The SD of predicted herd-level EB with reduced data sets were highest in the first wk p.p., tended to decrease toward wk 10 p.p., and generally increased with declining numbers of observations. This loss in precision of estimation with reduced data sets is illustrated in Figure 2. For each of the six final models, observed weekly EB from wk 1 to 10 p.p. is plotted against the observed EB minus 1 SD of the residual EB obtained with the reduced data sets. To correct for the differences between the six models with respect to the deviance between observed and estimated EB at particular weeks, the absolute value of this deviance (weekly residual mean) was further subtracted.

Mean observed and mean estimated EB for Models 3,4 , and 6 over the first 10 wk p.p. are presented in Table 12. Furthermore, SD of mean EB predicted with pooled samples of reduced data sets are depicted for each of these models. Again, a decrease in sample size

Table 8. Regression coefficients of Model $4 \dagger$ selected for estimation of energy balance [MJ $\left.\mathrm{NE}_{\mathrm{L}}\right]$.

\begin{tabular}{|c|c|c|c|c|}
\hline \multirow{2}{*}{$\frac{\text { Parameter }}{\text { Constant }}$} & \multirow{2}{*}{$\begin{array}{l}\text { Coefficient } \\
-29.06\end{array}$} & \multicolumn{2}{|c|}{$95 \%$ Confidence interval } & \multirow{2}{*}{$\begin{array}{r}\frac{P}{0.001} \\
0.04\end{array}$} \\
\hline & & -46.77 & -11.34 & \\
\hline NEFA, $\mu \mathrm{mol} / \mathrm{L}, \ln$ & -7.68 & -9.13 & -6.23 & $<0.001$ \\
\hline $\mathrm{T}_{4},{ }^{1} \mathrm{nmol} / \mathrm{L}, \ln$ & 12.14 & 8.37 & 15.91 & $<0.001$ \\
\hline Fat:lactose ratio milk, ln & -57.34 & -64.13 & -50.55 & $<0.001$ \\
\hline
\end{tabular}

$\dagger$ Cow is selected as random effect. Sample size $(n)=859$ test-day records. $R^{2}$ of fixed effects $=0.524, R^{2}$ of complete model $=0.821$.

${ }^{1} \mathrm{~T}_{4}=$ Thyroxine. 
Table 9. Regression coefficients of Model $5 \dagger$ selected for estimation of energy balance [MJ $\mathrm{NE}_{\mathrm{L}}$ ].

\begin{tabular}{|c|c|c|c|c|c|}
\hline \multirow{2}{*}{$\frac{\text { Parameter }}{\text { Constant }}$} & & \multirow{2}{*}{$\begin{array}{c}\text { Coefficient } \\
36.60\end{array}$} & \multicolumn{2}{|c|}{$95 \%$ Confidence interval } & \multirow{2}{*}{$\frac{P}{<0.001}$} \\
\hline & & & 28.86 & 44.34 & \\
\hline \multirow[t]{2}{*}{ CF-Group $^{1}$} & $\mathrm{C} 50^{2}$ & 0 & & & \\
\hline & $\mathrm{C} 30^{3}$ & -15.71 & -20.31 & -11.11 & $<0.001$ \\
\hline \multicolumn{2}{|l|}{ Week 1} & 0 & & & \\
\hline \multicolumn{2}{|l|}{ Week 2} & 5.37 & 2.33 & 8.42 & $<0.001$ \\
\hline \multicolumn{2}{|l|}{ Week 3} & 17.65 & 14.21 & 21.09 & $<0.001$ \\
\hline \multicolumn{2}{|l|}{ Week 4} & 21.14 & 17.47 & 24.80 & $<0.001$ \\
\hline \multicolumn{2}{|l|}{ Week 5} & 24.61 & 20.88 & 28.35 & $<0.001$ \\
\hline \multicolumn{2}{|l|}{ Week 6} & 25.17 & 21.52 & 28.83 & $<0.001$ \\
\hline \multicolumn{2}{|l|}{ Week 7} & 26.79 & 23.17 & 30.42 & $<0.001$ \\
\hline \multicolumn{2}{|l|}{ Week 8} & 28.35 & 24.80 & 31.89 & $<0.001$ \\
\hline \multicolumn{2}{|l|}{ Week 9} & 29.37 & 25.90 & 32.85 & $<0.001$ \\
\hline \multicolumn{2}{|l|}{ Week 10} & 30.76 & 27.32 & 34.20 & $<0.001$ \\
\hline \multicolumn{2}{|l|}{$\mathrm{ECM},{ }^{4} \mathrm{~kg}$} & -2.04 & -2.26 & -1.82 & $<0.001$ \\
\hline \multicolumn{2}{|c|}{ Fat:lactose ratio milk, ln } & -68.48 & -74.95 & -62.01 & $<0.001$ \\
\hline \multicolumn{2}{|c|}{ Milk acetone, $\mathrm{mmol} / \mathrm{L}, \mathrm{ln}$} & -1.30 & -2.23 & -0.37 & 0.007 \\
\hline
\end{tabular}

$\dagger$ Cow is selected as random effect. Sample size $(n)=859$ test-day records. $R^{2}$ of fixed effects $=0.695, R^{2}$ of complete model $=0.897$.

${ }^{1} \mathrm{CF}$-Group = Concentrate-feeding group.

${ }^{2} \mathrm{C} 30=30 \%$ of total DMI as concentrate from wk 1 to 10 p.p. ${ }^{5}$

${ }^{3} \mathrm{C} 50=50 \%$ of total DMI as concentrate from wk 1 to 10 p.p. ${ }^{5}$

${ }^{4} \mathrm{ECM}=$ Energy-corrected milk yield.

${ }^{5}$ p.p. = Postpartum.

or simulated herd size resulted in a loss in precision of prediction.

\section{DISCUSSION}

This study aimed to estimate individual and herdlevel EB at individual weeks in early lactation using blood and milk traits in high-yielding dairy cows. We analyzed whether herd-level EB can be accurately estimated even in small herds, when various metabolic, enzymatic, and endocrine blood traits were included in addition to milk components into the models for estimation of energy status. Furthermore, this study investigated whether mean-herd EB in early lactation can be predicted by use of pooled blood and milk samples. For this purpose, 90 Holstein cows kept on highly standardized conditions in a research farm were carefully studied over the first 10 wk p.p. Linear mixedeffects models with the cow selected as the repeatedly studied random effect were used for estimation of EB.
Decreased sample sizes and smaller herd sizes were simulated by random selection of test-days. These simulations were repeated 200 times in order to obtain stable SD for EB prediction with successively decreased data sets.

\section{Correlation of Energy Balance with Blood and Milk Traits}

Most coefficients of Pearson's correlations between the various blood and milk traits and EB early p.p. were in the well-known directions and reflected the well-orchestrated endocrine changes and metabolic adaptations in early lactation, i.e., enhanced mobilization of depot fat, skeletal muscle breakdown and favored partitioning of absorbed nutrients to the mammary gland to provide sufficient substrates for milk synthesis (Krebs, 1966; Blum et al., 1983; Kunz et al., 1985; Bauman et al., 1988; Ronge et al., 1988; Chilliard et al., 1998; Chilliard, 1999). The negative Pearson's

Table 10. Regression coefficients of Model $6 \dagger$ selected for estimation of energy balance [MJ NE $\left.E_{L}\right]$.

\begin{tabular}{|c|c|c|c|c|}
\hline \multirow{2}{*}{$\frac{\text { Parameter }}{\text { Constant }}$} & \multirow{2}{*}{$\begin{array}{c}\text { Coefficient } \\
19.38\end{array}$} & \multicolumn{2}{|c|}{$95 \%$ Confidence interval } & \multirow{2}{*}{$\frac{P}{0.015}$} \\
\hline & & 3.86 , & 34.90 & \\
\hline Milk protein, $\mathrm{g} / \mathrm{L}, \mathrm{ln}$ & -28.73 & -39.49 & -17.98 & $<0.001$ \\
\hline Milk urea, mmol/L & -5.32 & -6.94 & -3.69 & $<0.001$ \\
\hline Fat:lactose ratio milk, ln & -78.51 & -86.86 & -70.16 & $<0.001$ \\
\hline Milk acetone, $\mathrm{mmol} / \mathrm{L}, \mathrm{ln}$ & -1.83 & -2.99 & -0.66 & 0.002 \\
\hline
\end{tabular}

$\dagger$ Cow is selected as random effect. Sample size $(n)=859$ test-day records. $R^{2}$ of fixed effects $=0.330, R^{2}$ of complete model $=0.802$. 
MODEL 1

Observed - Predicted EB [MJ NEL / d]

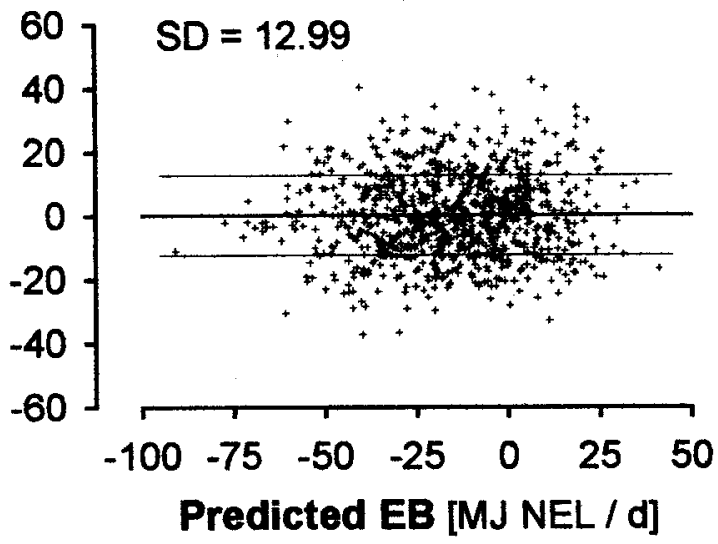

MODEL 3

Observed - Predicted EB [MJ NEL / d]

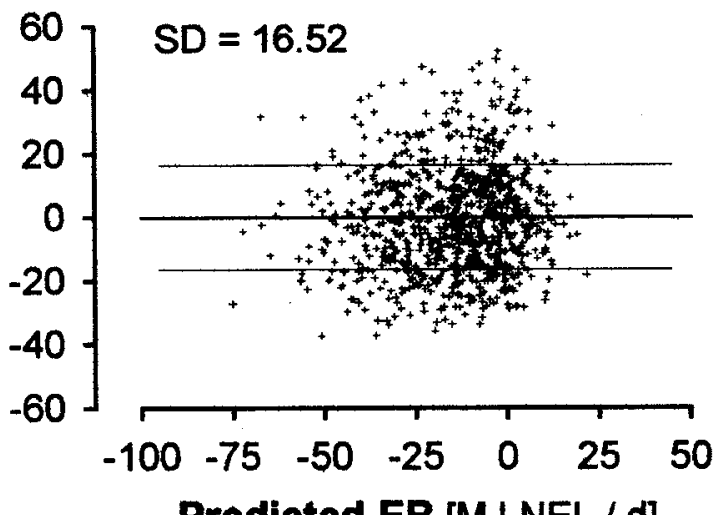

Predicted EB [MJ NEL / d]

MODEL 5

Observed - Predicted EB [MJ NEL / d]

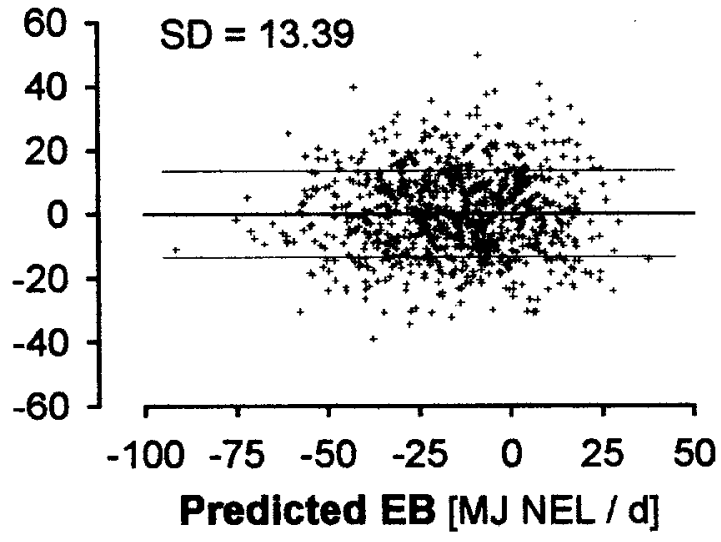

MODEL 2

Observed - Predicted EB [MJ NEL / d]

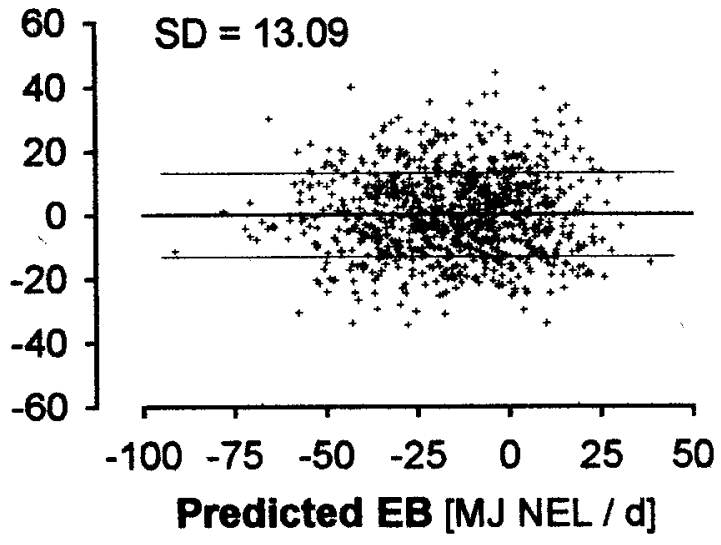

MODEL 4

Observed - Predicted EB [MJ NEL / d]

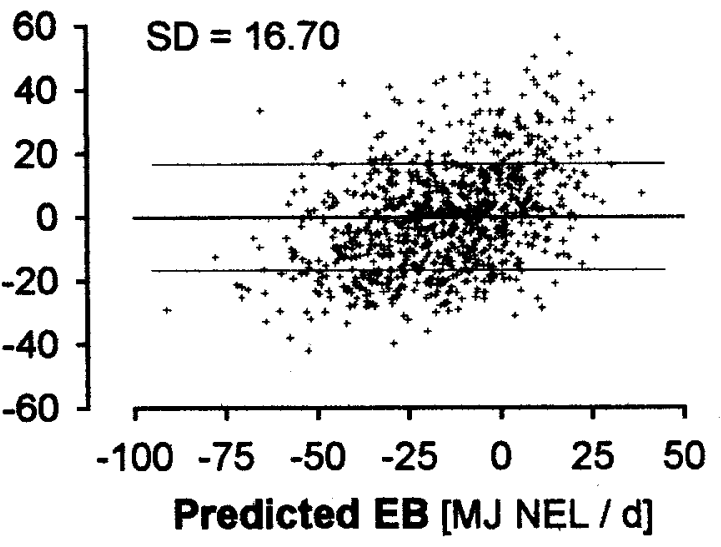

MODEL 6

Observed - Predicted EB [MJ NEL / d]

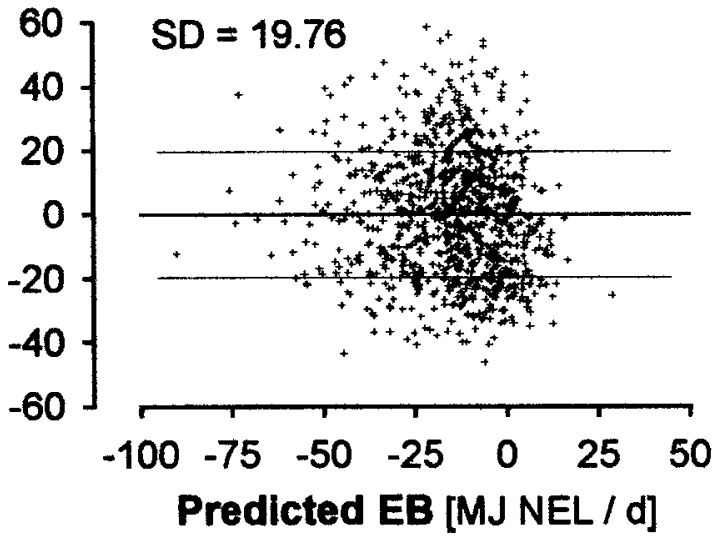

Figure 1. Residual plots of the six final models selected for estimation of energy balance $(\mathrm{EB})$ and $\mathrm{SD}$ of the residual EB ( $\mathrm{n}=859)$. 
Table 11. Mean observed and residual energy balance $\left(\mathrm{EB}, \mathrm{MJ} \mathrm{NE}_{\mathrm{L}}\right.$ ) and precision of predicted herd-mean EB at decreasing sample (n) and herd size in individual weeks.

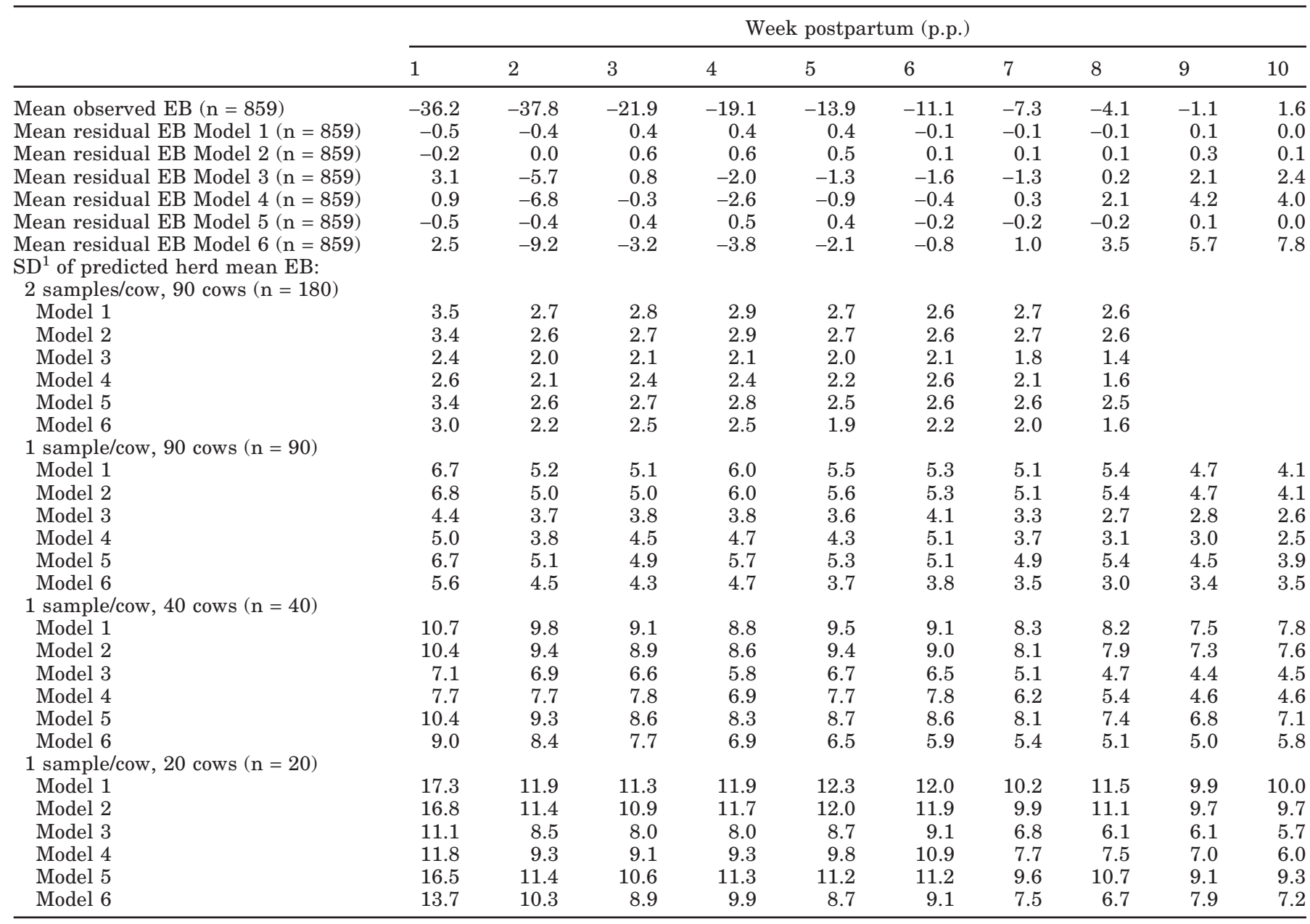

${ }^{1}$ Standard deviations of 200 predicted herd means obtained by repeated random sampling from a pool of 859 test-day records (90 cows, 10 weekly tests from wk 1 to 10 postpartum).

correlation of EB to milk protein was probably due to an effect of stage of lactation, i.e., a concomitant increase in EB and decrease in milk protein concentration as the colostrum effect disappeared and, therefore, was not contradictory to the positive regression coefficient of milk protein concentration in the multivariate mixed-effects model estimating EB. The same effect explains the negative Pearson's correlation of plasma albumin to EB, while the regression coefficient of albumin in the multivariate mixed-effects model was positive.

\section{Model Development and Estimation of Individual and Herd-Level EB}

Different models $(n=6)$ for estimation of EB using blood and milk traits were developed. In a first step, a best multivariate model with respect to precision of estimation of individual $\mathrm{EB}$ and $\mathrm{R}^{2}$ of the fixed effects was developed (Model 1). Further models with a reduced number of fixed effects and, partly, taking into account milk traits only, were developed with respect to practical applicability. Correlation of the fixed effects was examined prior to calculation in order to avoid colinearity. Whenever the absolute value of the coefficient of correlation between two variables exceeded $r=0.5$, the variable correlating stronger with EB was incorporated into the basic model and the other was omitted. As a result, $\mathrm{T}_{4}$ displaced $\mathrm{T}_{3}$ and the fat:lactose ratio in milk displaced the fat:protein ratio and milk fat; although using the fat:lactose ratio instead of the fat:protein ratio for estimation of EB is unusual. Nevertheless, Steen et al. (1996) demonstrated in Norwegian dairy herds, that high fat:lactose ratios were closely associated with elevated ketone 
MODEL 1

EB [MJ NEL / d]

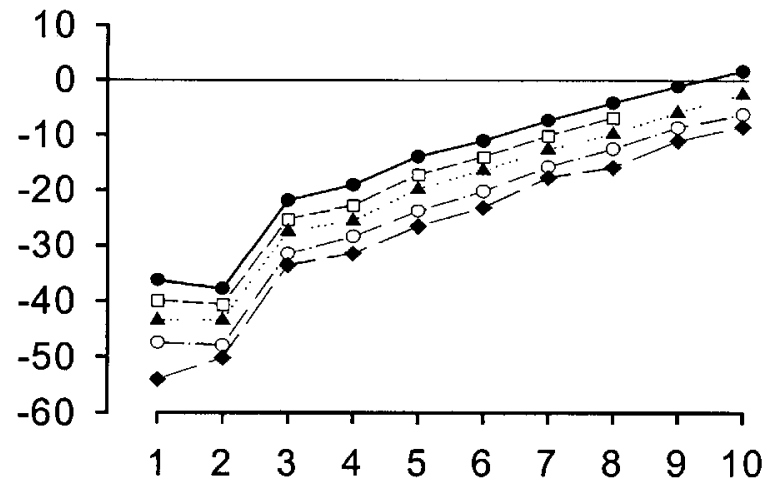

MODEL 3

EB [MJ NEL / d]

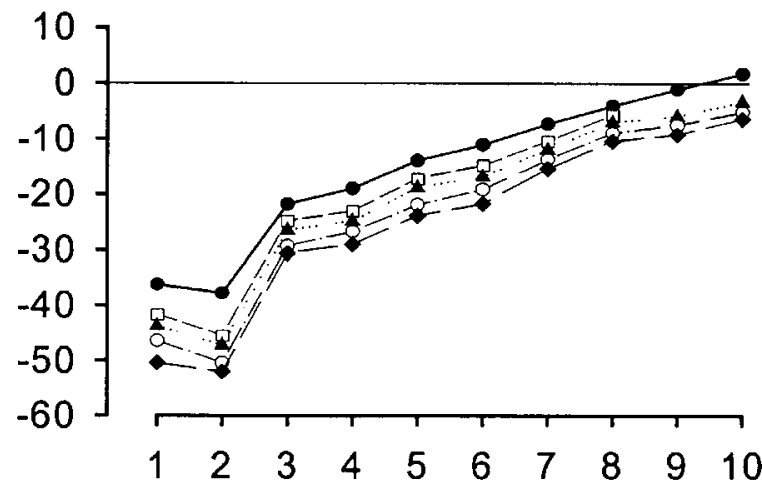

MODEL 5

EB [MJ NEL / d]

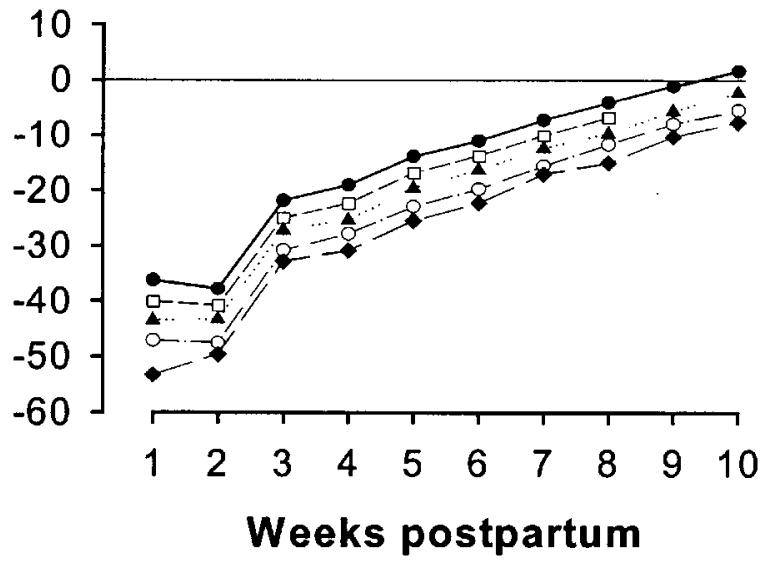

MODEL 2

EB [MJ NEL / d]

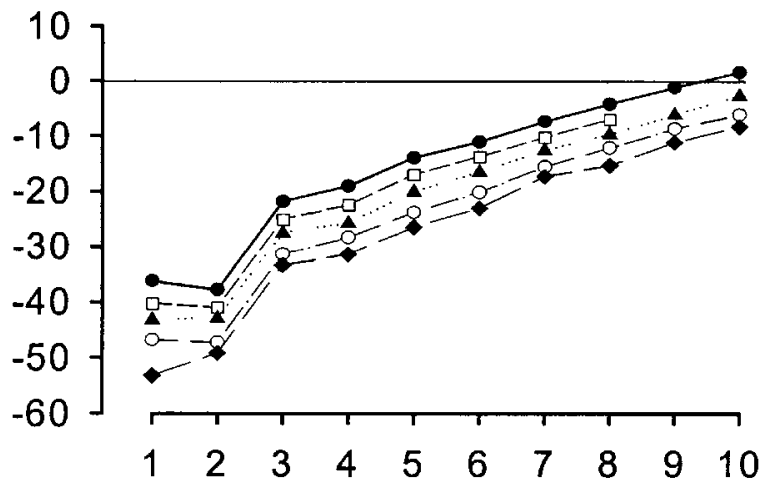

EB [MJ NEL / d]

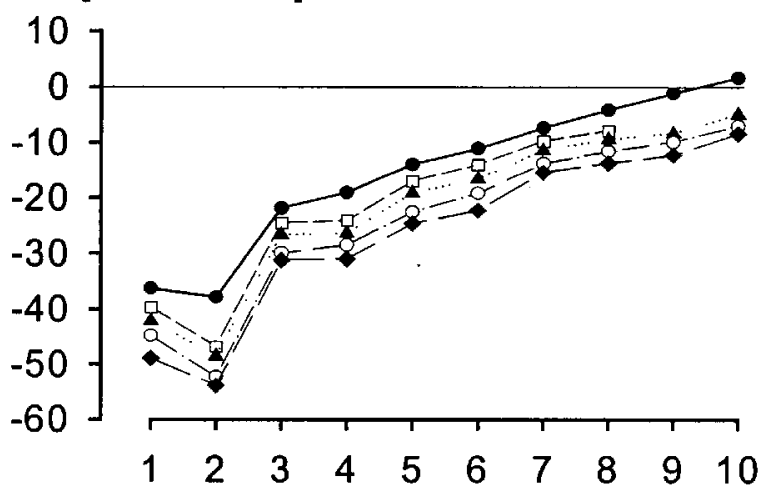

MODEL 6

EB [MJ NEL / d]

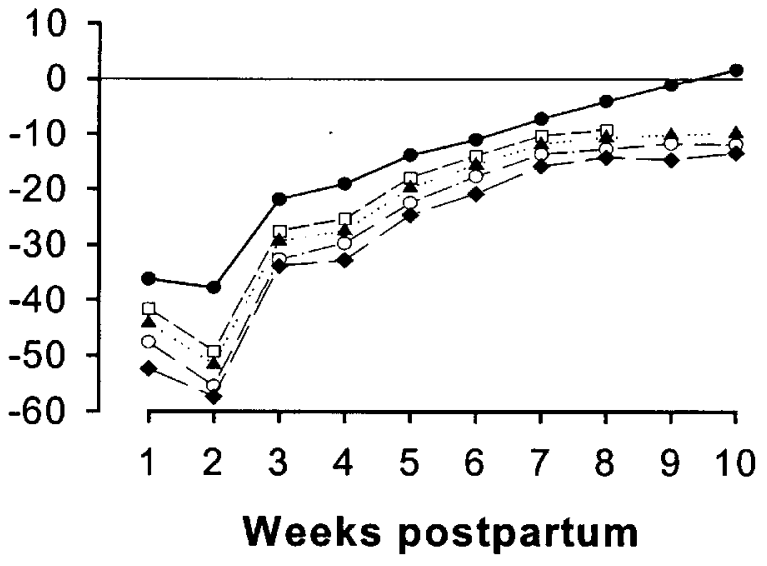

Figure 2. Herd means of postpartum energy balance (EB): observed and predicted means (PM) minus 1 SD of the means obtained by 200 repeated random selections of data-sets simulating reduced herd size (Table 11). $-\bullet-=$ observed mean $(\mathrm{n}=859)$; -- $\square--=\mathrm{PM}^{1}$ minus $1 \mathrm{SD}(\mathrm{n}=180) ; \cdots \mathbf{\Delta} \cdots=\mathrm{PM}^{1}$ minus $1 \mathrm{SD}(\mathrm{n}=90) ; \cdot-\mathrm{O}_{-} \cdot=\mathrm{PM}^{1} \operatorname{minus} 1 \mathrm{SD}(\mathrm{n}=40) ;-\bullet-=\mathrm{PM}^{1} \operatorname{minus} 1 \mathrm{SD}(\mathrm{n}=20)$. 
Table 12. Precision of predicted herd-mean energy balance $\left(\mathrm{EB}, \mathrm{MJ} \mathrm{NE}_{\mathrm{L}}\right.$ ) by pooling of individual samples at decreasing sample (n) and herd size in comparison with observed values.

\begin{tabular}{|c|c|c|c|c|}
\hline & Weeks & Model 3 & Model 4 & Model 6 \\
\hline Mean observed EB $(n=687)$ & $1-8$ & -19.0 & -19.0 & -19.0 \\
\hline Mean predicted EB $(\mathrm{n}=687)$ & $1-8$ & -18.1 & -18.1 & -17.5 \\
\hline Mean observed EB $(n=859)$ & $1-10$ & -15.2 & -15.2 & -15.2 \\
\hline Mean predicted EB $(\mathrm{n}=859)$ & $1-10$ & -14.8 & -15.2 & -15.3 \\
\hline \multicolumn{5}{|l|}{$\mathrm{SD}^{1}$ of predicted herd mean EB: } \\
\hline 2 samples/cow, 90 cows $(\mathrm{n}=180)$ & $1-8$ & 0.6 & 0.6 & 0.6 \\
\hline 1 sample/cow, 90 cows $(n=90)$ & $1-10$ & 1.5 & 1.5 & 1.4 \\
\hline 1 sample/cow, 40 cows $(n=40)$ & $1-10$ & 2.3 & 2.2 & 2.3 \\
\hline 1 sample/cow, 20 cows $(\mathrm{n}=20)$ & $1-10$ & 3.4 & 3.3 & 3.5 \\
\hline
\end{tabular}

${ }^{1}$ Standard deviations of 200 predicted herd means obtained by repeated random sampling from the pool of 859 test-day records ( 90 cows, 10 weekly tests from wk 1 to 10 postpartum).

body status and, thus, provided evidence that they are connected with the energy status.

In Model 1, the regression coefficients of the fixed effects reflect metabolic adaptation after parturition. Typically, energy status improved considerably with lactation week (Heuer et al., 2000). The $\mathrm{T}_{4}$ was positively and NEFA, creatinine, ECM, and fat:lactose ratio were negatively associated with $\mathrm{EB}$, which was more negative in C30 compared with C50 cows. The measure of determination of the complete model was high. The fixed effects explained most of the variability of EB, while the cow as random effect accounted only for a small $R^{2}$. Nevertheless, precision of estimation of individual EB indicated in 1 SD of observed minus estimated EB was rather low. In Model 2, stepwise elimination of blood and milk traits (creatinine) leaving the three most informative ones (NEFA, $\mathrm{T}_{4}$, and fat:lactose ratio) resulted in the same high $R^{2}$ of the complete model, and only in minor decreases in $R^{2}$ of the fixed effects and in the precision of estimation of individual EB, respectively. For Model 1 as well as for Model 2, EB estimated by use of the complete data set $(\mathrm{n}=859)$ was very close to the observed EB. However, decreased sample and herd sizes considerably decreased precision of prediction of herd-level EB, especially at the onset of metabolic adaptation after parturition in wk 1 p.p. A decrease in variance of EB from wk 1 to 10 p.p. and a more stable metabolic state toward wk 10 p.p. might have resulted in an increased precision of prediction.

Models 3 and 4 aimed to estimate EB by using blood and milk traits as the only fixed effects, i.e., information about CF-group, sampling week, and ECM was omitted. In Model 3, NEFA, albumin, fat:lactose ratio, and milk urea were negatively, and cholesterol and $\mathrm{T}_{4}$ were positively associated with EB, reflecting metabolic adaptation after parturition. Pearson's correlation between milk urea and EB was positive, reflecting an increase of urea concomitant with DMI. However, a decrease in energy supply results in decreased ammonia fixation by microbes in the rumen as well as an increased AA catabolism in the liver and, consequently, leads to increased urea synthesis (Oltner and Wiktorsson, 1983), as evidenced by the negative association between EB and milk urea. The remaining three most informative traits in Model 4 were the same as in Model 2. In Models 3 and 4 , the $\mathrm{R}^{2}$ of the complete models were again relatively high. However, the fixed effects, which are the physically measurable and recordable data to estimate EB, explained considerably less of the variability of EB, while the cow as random effect accounted for a greater part of variance of $\mathrm{EB}$ compared with Models 1 and 2. Mainly by elimination of the fixed-effect sampling week, EB could be less precisely estimated and the mixed model attributed some of the weekly variation of $\mathrm{EB}$ to the cow, explaining why the cow accounted for a greater part of variance of EB in Models 3 and 4. Hence, precision of estimation of individual EB was considerably lower in Models 3 and 4 than in Models 1 and 2. Mean estimated EB with Models 3 and 4 using the complete data set ( $\mathrm{n}=859$ ) deviated considerably from mean-observed EB, especially in wk 2 and 4 p.p. and, again, toward wk 10 p.p. Again, these deviations from the observed means, which were stronger for Model 4 than for Model 3 , were due to the elimination of the fixed-effect week in Models 3 and 4 compared with Models 1 and 2. In Models 1 and 2, the categorical variable sampling week corrected for the curvilinear trend of EB in the course of lactation, while Models 3 and 4 contained exclusively variables at the continuous scale and, therefore, failed to estimate mean EB at each individual week, even when considering the complete data set $(n=859)$. Once more, precision of prediction decreased considerably with a decrease in sample and herd size, and the increase in precision of EB from wk 1 to wk 10 p.p. can be explained with a decrease in variance of $\mathrm{EB}$ 
over this period due to a more stable metabolic state toward wk 10 p.p.

In Models 5 and 6, no blood traits were used to estimate EB. Model 5 comprised CF-group, sampling week, and ECM and was therefore similar to Models 1 and 2, while Model 6 comprised milk components and milk AC and, thus, was similar to Models 3 and 4. The regression coefficients of CF-group and ECM were in the same range as in Models 1 and 2. The fat:lactose ratio and milk AC were negatively associated with $\mathrm{EB}$ and reflected physiologic processes, e.g., mobilization of body fat, in early lactation (Steen et al., 1996; Aeberhard et al., 2001a). The fixed-effect milk corrected for the excursive progression of EB. Therefore, EB estimated using the complete data set $(\mathrm{n}=859)$ with Model 5 was very close to the observed EB at each of the studied weeks, which is similar in Models 1 and 2. The $\mathrm{R}^{2}$ of the complete model and of the fixed effects was barely lower than those of the models containing blood traits in addition, and precision of estimation of EB at the individual animal level was in the same range as in Models 1 and 2. The EB at decreasing-herd and sample sizes was also very similar to Models 1 and 2. Therefore, use of blood traits in addition to milk traits does not result in higher precision of prediction of individual and herd-level EB, regardless of sample size. In Model 6, negative associations of milk protein, urea, $\mathrm{AC}$, and fat:lactose ratio with $\mathrm{EB}$ reflected the physiological processes in early lactation, as discussed in the previous sections. The $\mathrm{R}^{2}$ of the complete Model and of the fixed effects were lower than in Models 1 to 5, but the cow accounted for considerably more of the variance than in Models 1 to 5. Precision of estimation of individual EB was lowest compared with the other five models. For the same reasons as in Models 3 and 4, estimated EB using the complete data set $(\mathrm{n}=859)$ deviated considerably from mean observed EB at several weeks. Apart from the deviation of estimated from observed EB, especially in wk 2 p.p., precision of prediction of EB at herd level at reduced sample and herd size was as good for Model 6 as for any of the other models.

Prediction of mean overall herd-level EB over the first $10 \mathrm{wk}$ of lactation by pooling samples was precise with each of the applicable models for this purpose (Models 3, 4, and 6), even with reduced data sets and smaller herd size. However, samples were selected randomly from wk 1 to 10 p.p. and were therefore uniformly distributed across this period. Accumulation of calvings either at the beginning or at the end of the sampling period would result in a marked loss in precision of prediction. Therefore, distribution of sampling has to be considered. Furthermore, no information about EB at a particular week can be obtained when pooling the samples. However, estimation of occurrence and degree of EB nadir might be of particular interest for taking management decisions.

\section{CONCLUSIONS}

Estimating EB using blood and milk traits has a great practical potential in monitoring nutritional status p.p. of high-yielding dairy cows on a herd level. Model 5, comprising the fixed-effects concentrate feeding strategy and week of lactation at the categorical scale and ECM, fat:lactose ratio, and milk acetone at the continuous scale, offers a useful tool to precisely estimate the early p.p. herd-level energy status at individual weeks. For this purpose the monthly sampled milk test-day records, as provided by several breeding associations, can be used. However, because precision of estimation decreases tremendously with decreasing sample and herd sizes, estimation of herd-level EB at individual weeks is only suitable in large herds, with herd sizes of $\geq 100$ cows if calving is highly seasonal and of $\geq 400$ cows if calving is uniformly distributed around the year. Estimation of EB at the individual animal level is not precise enough to allow practical application, neither by use of milk traits alone, nor by use of milk and blood traits. Estimation of overall mean herd-level EB over the first 10 wk of lactation using pooled samples is precise. However, information on herd-level EB in particular weeks is lost when samples are pooled. Remarkably, the use of blood traits in addition to milk traits does not result in higher precision of prediction of individual and herd-level EB, regardless of sample size.

\section{ACKNOWLEDGMENTS}

We thank the staff of the research station Chamau, Institute of Animal Science, Swiss Federal Institute of Technology, Huenenberg, Zug, Switzerland, for their great support during the establishment and realization of the experiments. We also thank the Swiss Association for Artificial Insemination for the financial support of the leptin determinations. Ovine leptin for radioimmunoassay was kindly donated by Dr. A. Gretler, Institute of Biochemistry, Food Science and Nutrition, Rehovot, Israel. Dr. C. Delavaud, Herbivore Research Unit, INRA, St-Genès-Champanelle, France, is greatly acknowledged for her advice in the adaptation of the leptin radioimmunoassay.

\section{REFERENCES}

Aeberhard, K., R. M. Bruckmaier, U. Kuepfer, and J. W. Blum. 2001a. Milk yield and composition, nutrition, body conformation traits, body condition scores, fertility and diseases in high-yielding dairy cows-Part 1. J. Vet. Med. A 48:97-110. 
Aeberhard, K., R. M. Bruckmaier, and J. W. Blum. 2001b. Metabolic, enzymatic and endocrine status in high-yielding dairy cowsPart 2. J. Vet. Med. A 48:111-127.

Allen, M. S. 2000. Effects of diet on short-term regulation of feed intake by lactating dairy cattle. J. Dairy Sci. 83:1598-1624.

Andersson, L. 1988. Subclinical ketosis in dairy cows. Vet. Clin. North Am. Food Anim. Pract. 4:233-251.

Bauman, D. E., C. J. Peel, W. D. Steinhour, P. J. Reynolds, H. F. Tyrrell, A. C. G. Brown, and G. L. Haaland. 1988. Effect of bovine somatotropin on metabolism of lactating dairy cows: Influence on rates of irreversible loss and oxidation of glucose and nonesterified fatty acids. J. Nutr. 118:1031-1040.

Blum, J. W., F. Jans, W. Moses, D. M. Fröhli, M. Zemp, M. Wanner, I. C. Hart, R. Thun, and U. Keller. 1985. Twenty-four-hour pattern of blood hormone and metabolite concentrations in highyielding dairy cows: Effects of low or high amounts of starch, or crystalline fat. J. Vet. Med. A 32:401-418.

Blum, J. W., P. L. Kunz, H. Leuenberger, K. Gautschi, and M. Keller. 1983. Thyroid hormones, blood plasma metabolites, and haematological parameters in relationship to milk yield in dairy cows. Anim. Prod. 36:93-104.

Bruckmaier, R. M., L. Gregoretti, F. Jans, D. Faissler, and J. W. Blum. 1998. Longissimus dorsi muscle diameter, backfat thickness, body condition scores, and skinfold values related to metabolic and endocrine traits in lactating dairy cows fed crystalline fat or free fatty acids. J. Vet. Med. A 45:397-410.

Butler, W. R., and R. D. Smith. 1989. Interrelationships between energy balance and postpartum reproductive function in dairy cattle. J. Dairy Sci. 72:767-783.

Butler, W. R. 2000. Nutritional interactions with reproductive performance in dairy cattle. Anim. Reprod. Sci. 60-61:449-457.

Chilliard, Y., F. Bocquier, and M. Doreau. 1998. Digestive and metabolic adaptations of ruminants to undernutrition, and consequences on reproduction. Reprod. Nutr. Dev. 38:131-152.

Chilliard, Y. 1999. Metabolic adaptations and nutrient partitioning in the lactating animal. Pages 503-552 in Biology of Lactation. J. Martinet, L. H. Houdebine, and H. H. Head, ed. Collection Mieux Comprendre, INRA Editions, Paris, France.

Delavaud, C., F. Bocquier, Y. Chilliard, D. H. Keisler, A. Gertler, and G. Kann. 2000. Plasma leptin determination in ruminants: Effect of nutritional status and body fatness on plasma leptin concentration assessed by a specific RIA in sheep. J. Endocrinol. 165:519-526.

Dohoo, I. R., and S. W. Martin. 1984. Subclinical ketosis: Prevalence and associations with production and disease. Can. J. Comp. Med. 48:1-5.

Grieve, D. G., S. Korver, Y. S. Rijpkema, and G. Hof. 1986. Relationship between milk composition and some nutritional parameters in early lactation. Livest. Prod. Sci. 14:239-254.

Gustafsson, A. H., and U. Emanuelson. 1996. Milk acetone concentration as an indicator of hyperketonaemia in dairy cows: The critical value revised. Anim. Sci. 63:183-188.

Heuer, C., Y. H. Van Straalen, Y. H. Schukken, A. Dirkzwanger, and J. P. Noordhuizen. 2000. Prediction of energy balance in a high-yielding dairy herd in early lactation: Model development and precision. Livest. Prod. Sci. 65:91-105.

Ingvartsen, K. L., and J. B. Andersen. 2000. Integration of metabolism and intake regulation: A review focusing on periparturient animals. J. Dairy Sci. 83:1573-1597.
Jans, F., and J. Kessler. 1999. Fütterungsempfehlungen für die Milchkuh. Pages 83-112 in Fütterungsempfehlungen und Nährwerttabellen für Wiederkäuer. Eidgenössische Forschungsanstalt für Nutztiere, Posieux, Switzerland. 4th ed. Landwirtschaftliche Lehrmittelzentrale, Zollikofen, Switzerland.

Kessler, J. 1999. Mineralstoffe und Vitamine. Pages 39-50 in (Ed.) Fütterungsempfehlungen und Nährwerttabellen für Wiederkäuer. Eidgenössische Forschungsanstalt für Nutztiere, Posieux, Switzerland. 4th ed. Landwirtschaftliche Lehrmittelzentrale, Zollikofen, Switzerland.

Krebs, H. A. 1966. Bovine ketosis. Vet. Rec. 78:187-192.

Kunz, P. L., J. W. Blum, I. C. Hart, H. Bickel, and J. Landis. 1985. Effects of different energy intakes before and after calving on food intake, performance and blood hormones and metabolites in dairy cows. Anim. Prod. 40:219-231.

Lucy, M. C., J. Beck, C. R. Staples, H. H. Head, R. L. de la Sota, and W. W. Thatcher. 1992. Follicular dynamics, plasma metabolites, hormones and insulin-like growth factor I (IGF-1) in lactating cows with positive or negative energy balance during the preovulatory period. Reprod. Nutr. Dev. 32:331-341.

Macleod, G. K., D. G. Grieve, I. McMillan, and G. C. Smith. 1984. Effect of varying protein and energy densities in complete rations fed to cows in first lactation. J. Dairy Sci. 67:1421-1429.

Markusfeld, O. 1984. Factors responsible for post parturient metritis in dairy cattle. Vet. Rec. 114:539-542.

Marstorp, P., T. Anfält, and L. Andersson. 1983. Determination of oxidized ketone bodies in milk by flow injection analysis. Anal. Chim. Acta 149:281-289.

MathSoft (1999) S-PLUS 2000, Professional Release (1988-1999). MathSoft Inc., Seattle, WA, USA.

Oltner, R., and H. Wiktorsson. 1983. Urea concentrations in milk and blood as influenced by feeding varying amounts of protein and energy to dairy cows. Livest. Prod. Sci. 10:457-467.

Pinheiro, J. C., and D. M. Bates. 2000. Mixed-effects models in S and S-PLUS. Springer, New York, NY.

RAP. 1999. Fütterungsempfehlungen und Nährwerttabellen für Wiederkäuer. Eidgenössische Forschungsanstalt für Nutztiere, Posieux, Switzerland. 4th ed. Landwirtschaftliche Lehrmittelzentrale, Zollikofen, Switzerland.

Reist, M., A. Koller, A. Busato, U. Kuepfer, and J. W. Blum. 2000. First ovulation and ketone body status in the early postpartum period of dairy cows. Theriogenology 54:685-701.

Ronge, H., J. W. Blum, F. Clément, F. Jans, H. Leuenberger, and H. Binder. 1988. Somatomedin C in dairy cows related to energy and protein supply and to milk production. Anim. Prod. 47:165-183.

Staples, C. R., W. W. Thatcher, and J. H. Clark. 1990. Relationship between ovarian activity and energy status during the early postpartum period of high producing dairy cows. J. Dairy Sci. 73:938-947.

Steen, A., O. Osteras, and H. Gronstol. 1996. Evaluation of bulk milk analyses of acetone, urea, and the fat-lactose-quotient as diagnostic aids in preventive veterinary medicine. J. Vet. Med. A 43:261-269.

Suriyasathaporn, W., C. Heuer, E. N. Noordhuizen-Stassen, and Y. H. Schukken. 2000. Hyperketonemia and the impairment of udder defense: A review. Vet. Res. 31:397-412. 